\title{
KONSEP KAMPUS MERDEKA BELAJAR DALAM MENGHADAPI ERA REVOLUSI INDUSTRI 4.0
}

\author{
Zainal \\ Universitas Tanjungpura, Pontianak
}

Email korespondensi: zaienal58@gmail.com

\begin{abstract}
Abstrak
10.26418/pipt.2021.20

Merdeka Belajar-Kampus Merdeka adalah kebijakan Menteri Pendidikan dan Kebudayaan yang memiliki tujuan mendorong mahasiswa agar menguasai berbagai keilmuan untuk memasuki dunia kerja. Mengenai kebijakan Merdeka Belajar Kampus Merdeka sesuai Standar Nasional Pendidikan Tinggi Berdasarkan Permendikbud Nomor 03 Tahun 2020. Dalam menghadapi dunia industri yang semakin maju serta perkembangan zaman berubah, pemerintah berinisiatif membuat kebijakan baru dalam dunia pendidikan khususnya yaitu kampus merdeka belajar. Menurut Bapak Nadiem Makarim selaku menteri pendidikan dan kebudayaan dan Konsep Kampus Merdeka ini dapat membantu mahasiswa menuju era revolusi 4.0 yang penuh dengan rintangan sehingga dengan perubahan konsep ini pada perguruan tinggi diharapkan seluruh mahasiswa siap dan tanggap dalam menghadapi dunia kerja. Kreatif dan inovatif dalam membangun etos kerja sehingga generasi bangsa Indonesia akan menjadi generasi yang berguna bukan hanya untuk dirinya namun juga negaranya.
\end{abstract}

Kata kunci: Konsep Merdeka Belajar, Revolusi Industri 4.0

\section{PENDAHULUAN}

Pendidikan mempunyai peran yang sangat penting sebagai strategi untuk menghadapi persaingan yang semakin meningkat serta harus mampu menghadapi segala perubahan zaman yang semakin mendunia saat ini sehingga sebagai generasi muda kita akan mampu membentengi segala perubahan yang akan terjadi di negara kita ini.

Bangsa Indonesia memiliki SDM (Sumber Daya Manusia) yang harus bisa beradaptasi dengan segala perubahan yang ada agar menjadi manusia yang berkualitas menjadi sesuatu hal yang penting dan menjadi perhatian bersama dalam upaya menciptakan NKRI (Negara Kesatuan Republik Indonesia) ini menjadi bangsa yang maju, karena kreativitas dan inovasi menjadi faktor penentu suatu keberhasilan di era 4.0 terlebih saat pandemi COVID-19. Generasi milenial jika hanya bertindak sebagai pengguna yang pasif tidak akan mampu bersaing dalam menghadapi perubahan yang semakin canggih. Selain itu, generasi milenial juga harus mampu menjadi pemimpin dalam membangun inovasiinovasi terbaru, serta mempunyai wawasan yang luas menghadapi perkembangan teknologi, untuk menyongsong era revolusi industri 4.0 ini. Dengan berpikir kritis dan tidak terjerumus ke dalam hal yang negatif mahasiswa harus berperan aktif didalamnya.

Sebagai aset bangsa, generasi muda harus diberikan kebebasan dalam berpikir, sehingga mereka akan mampu dalam mengembangkan inovasi berfikir yang kreativitas agar menjadi generasi muda yang bermanfaat bagi bangsa dan negara. Sebagai generasi muda tentunya harus mampu melatih pola pikir, memilah informasi yang benar dan yang salah, di dalam pesatnya pertumbuhan teknologi saat ini.

Oleh karena itu, topik ini diangkat penulis dengan tujuan untuk mengetahui lebih rinci dan menganalisis mengapa konsep merdeka belajar dibutuhkan mahasiswa dalam menyongsong era revolusi industri 4.0, serta bagaimana rencana penerapan konsep kampus merdeka tersebut dilakukan. Sehingga dengan adanya perubahan sistem dunia pendidikan pada perguruan tinggi mampu melahirkan 
generasi yang jauh lebih baik lagi dan terus berkembang sejalan dengan perkembangan zaman.

\section{METODOLOGI}

Teknik pengumpulan data merupakan sebuah cara yang digunakan untuk mengumpulkan data-data penelitian dan secara sistematis dapat memberikan kejelasan dari data yang diperoleh. Teknik pengumpulan data yang digunakan peneliti dalam penelitian ini adalah metode pengumpulan data pustaka yaitu peneliti memanfaatkan fasilitas yang ada di perpustakaan, seperti buku, majalah, dokumen, catatan kisah-kisah sejarah, maupun laporan hasil penelitian dari penelitian terdahulu. Selain itu penulis juga menggunakan sumber lain yaitu melalui makalah, jurnal, dan sumber-sumber lain yang relevan. Peneliti mencatat hal- hal penting yang terdapat pada sumber tersebut sebagai landasan untuk menyelesaikan penelitian ini.

\section{HASIL DAN PEMBAHASAN}

\section{Definisi Kampus Merdeka}

Merdeka belajar adalah pemberian kebebasan dan wewenang kepada lembaga pendidikan, sehingga dosen dan mahasiswa dapat memilih dan mengatur sendiri bidang yang mereka sukai. Menurut Bapak Nadiem Makarim selaku Menteri pendidikan dan kebudayaan mengatakan bahwa kampus merdeka belajar merupakan kebijakan yang bertujuan mendorong mahasiswa untuk menguasai berbagai keilmuan yang bermanfaat untuk membangun dunia kerja. Mahasiswa dapat memilih mata kuliah yang mereka inginkan dalam kebijakan ini.

Kampus Merdeka merupakan wujud pembelajaran kampus yang otonom dan fleksibel sehingga tercipta cara belajar yang lebih inovatif sesuai dengan kemajuan zaman, tidak otoriter, dan sesuai dengan kebutuhan mahasiswa. Kampus merdeka adalah sebuah konsep baru yang menginginkan kemerdekaan belajar bagi mahasiswa pada perguruan tinggi yang dipilih. Dasar dari konsep ini terlahir dari hasil tindak lanjut dari sebuah konsep yang sebelumnya yaitu merdeka belajar. Konsep ini adalah penerapan dari visi misi yang dicetus oleh Presiden Joko Widodo yang berupaya meningkatkan perubahan SDM yang lebih unggul. Konsep kampus merdeka ini akan segera direalisasikan dengan tujuan untuk menemukan generasi bangsa yang lebih berkualitas.

Sesuai dengan Permendikbud Nomor 3 Tahun 2020 tentang Standar Nasional Pendidikan Tinggi Pasal 18 menjelaskan bahwa pemenuhan masa dan beban belajar bagi mahasiswa program sarjana atau sarjana terapan dapat dilaksanakan melalui Kebijakan Kampus Merdeka ini meliputi:

1. Mengikuti seluruh proses pembelajaran dalam program studi pada PT sesuai masa dan beban belajar.

2. Mengikuti proses pembelajaran di dalam program studi untuk memenuhi sebagian masa dan beban belajar dan sisanya mengikuti proses pembelajaran di luar program studi.

Pada Kampus Merdeka kesempatan serta tantangan diberikan dalam rangka pemberian kesempatan untuk pengembangan kreativitas, kapasitas, kepribadian, dan kebutuhan mahasiswa, serta mengembangkan kemandirian dalam mencari dan menemukan pengetahuan melalui kenyataan dan dinamika lapangan seperti persyaratan kemampuan, permasalahan ril, interaksi sosial, kolaborasi, manajemen diri, tuntutan kinerja, target dan lainnya.

Untuk menerapkan konsep kampus merdeka ini, wewenang dalam kebebasan kepada mahasiswa selama dua semester dalam program belajar yang kegiatannya dilakukan di luar kelas. Konsep ini nantinya menjadi dasar agar mahasiswa lebih mudah bersosialisasi dengan lingkungan di luar kampus. Oleh sebab itu, secara tidak langsung mahasiswa akan diajak untuk belajar dan bersosialisasi di lingkungan masyarakat. Kebijakan tersebut diharapkan agar dapat mengenalkan kepada mahasiswa 
sejak dini dunia kerja kepada mahasiswa agar nantinya mereka akan lebih siap terjun pada dunia kerja setelah lulus dalam perkuliahan.

Sebuah terobosan baru yang dibuat oleh Bapak Nadiem pada hakikatnya mendorong mahasiswa untuk mampu belajar selama dua semester di luar kampus. Perencanaan tersebut adalah solusi untuk memberikan kesempatan kepada mahasiswa dalam menentukan mata kuliah mana yang mereka inginkan. Tujuannya agar mahasiswa memiliki kemampuan dalam menguasai beragam keilmuan yang bermanfaat jika mereka berada di dunia luar.

\section{Definisi Era Revolusi Industri 4.0}

Revolusi Industri adalah kondisi yang banyak mempengaruhi aspek kehidupan dalam perubahan globalisasi. Adanya perubahan revolusi industri tampak pada proses produksi yang sulit, membutuh waktu yang lama, membutuh biaya atau modal yang mahal sekarang menjadi lebih mudah, lebih cepat, dan lebih murah.

Revolusi industri keempat terjadi pada abad ke-21, dimana pada masa itu terjadi perkembangan teknologi yang sangat pesat. Semakin berkembangnya teknologi membuat kekhawatiran yang besar bagi masyarakat sekarang ini. Mereka merasa khawatir akan kehilangan pekerjaan mereka, karena ketika kemajuan teknologi ini berkembang terus menerus tentunya pekerjaan- pekerjaan mereka akan digantikan oleh kecanggihan teknologi tersebut. (Fonna, 2019).

Dalam dunia pendidikan adanya revolusi Perkembangan informasi dan teknologi tidak dapat dihindari dan menjadi bagian penting yang harus dikuasai oleh generasi bangsa ini. Guru merupakan ujung tombak dalam pendidikan, tanpa adanya dedikasi dari seorang guru pendidikan tidak akan berjalan dengan efektif. Dalam hal ini sebagai seorang pendidik guru harus mampu menyeimbangkan antara sistem pembelajaran dengan teknologi yang nantinya akan diimplementasikan pada proses belajar yang semakin hari harus lebih inovatif lagi. Dengan kata lain guru harus mampu menginovasi pembelajaran dari yang klasik menuju modernisasi. Selain itu guru juga harus mampu menyatukan antara berbagai metode pembelajaran dengan teknologi, sehingga dapat membantu siswa memahami berbagai masalah dalam pendidikan. Keterkaitan antara teknologi dan pendidikan harus sejalan dan mampu menciptakan kegiatan belajar yang baik dalam keadaan apapun dan di manapun.

Inovasi pembelajaran 4.0 mengharuskan adanya perubahan pada penguasaan metode pembelajaran oleh pendidik melalui aplikasi berbasis teknologi yang lebih inovatif di dalam kegiatan proses belajar di kelas, serta pengembangan dalam pembelajaran. Untuk berinovasi dalam menggunakan metode pembelajaran guru dapat memanfaatkan seluruh potensi yang ada di lingkungan sekitar dengan penyesuaian keadaan dan penyesuaian karakteristik peserta didik, termasuk halnya dalam penguasaan teknologi serta penerapannya.

Berbagai cara yang harus dilakukan dalam Inovasi pembelajaran 4.0. Pendidik harus menguasai metode pembelajaran yang selama ini diterapkan. Adapun mengadopsi dan mengembangkan metode pembelajaran yang sudah ada dengan kreativitas sendiri yang beraneka ragam adalah langkah awal yang dapat dilakukan dalam rangka pembelajaran 4.0 (Joenaidy, 2019)

Inovasi pembelajaran 4.0 juga dapat dilakukan dengan berbagai cara, salah satunya yaitu pendidik tentunya menguasai metode pembelajaran yang selama ini diterapkan, penggunaan metode belajar yang bervariatif serta mampu menyesuaikan dengan keadaan peserta didik adalah upaya yang sangat baik dilakukan di dalam proses pembelajaran, sehingga akan tercipta Suasana belajar yang mampu memacu minat belajar yang lebih baik lagi.

\section{Latar Belakang Terjadinya Perubahan Kampus Merdeka Belajar Era Revolusi Industri 4.0}

Untuk mempersiapkan mahasiswa dalam menghadapi segala perubahan yang 
terjadi baik itu perubahan sosial, budaya, serta kemajuan teknologi yang sangat pesat, maka kesiapan intelektual dan mental berkompetisi antar mahasiswa harus disiapkan lebih matang lagi khususnya dalam dunia perkuliahan. Pendidikan dan dunia kerja tidak hanya mempengaruhi dunia industri tetapi juga untuk menjamin masa depan yang berubah dengan sangat cepat. Kampus diharapkan dapat merancang serta mampu mengaplikasikan proses pembelajaran yang inovatif dan kreatif agar mahasiswa dapat meraih pencapaian pembelajaran baik pencapaian pengetahuan, dan keterampilan secara optimal.

Program utama dalam konsep kampus merdeka adalah kemudahan pembukaan program studi baru, perubahan sistem akreditasi perguruan tinggi, kemudahan perguruan tinggi negeri menjadi PTN berbadan hukum, dan hak belajar tiga semester di luar program studi. Disana semua mahasiswa diberikan kebebasan yang sama saat mengambil SKS di luar program studi tiga semester tersebut. Kesempatan mengambil mata kuliah di luar program studi selama satu semester dan dua semester melaksanakan aktivitas pembelajaran di luar kampus.

Contoh bentuk kegiatan belajar di luar kampus misalnya, melakukan praktik kerja di bidang industri atau tempat kerja yang relevan atau sesuai bidang studi yang diampu, melaksanakan proyek pengabdian kepada masyarakat di desa, mengajar di satuan pendidikan, mengikuti pertukaran mahasiswa, melakukan penelitian, melakukan kegiatan kewirausahaan, membuat studi/proyek independen, dan mengikuti program kemanusiaan dan lain sebagainya. Harus adanya bimbingan dosen dalam kegiatan tersebut. Dengan Adanya program kampus merdeka akan menambah pengalaman yang dapat dikaitkan dengan kehidupan mahasiswa sehingga mampu meningkatkan kompetensi mahasiswa siap kerja.

Sistem pembelajaran kampus merdeka yaitu sistem pembelajaran yang menitikberatkan pada mahasiswa seutuhnya.
Pembelajaran ini akan memberikan kesempatan kepada mahasiswa untuk pengembangan inovasi, kreativitas, kapasitas, kepribadian, dan kebutuhan mahasiswa, serta mengembangkan kemandirian dalam mencari dan menemukan pengetahuan melalui kenyataan dan dinamika lapangan seperti persyaratan kemampuan, permasalahan yang nyata, interaksi sosial dalam masyarakat, kolaborasi, manajemen diri, tuntutan kinerja, target dan pencapaian lulusan yang sesuai dengan perkembangan zaman, kemajuan IPTEK, tuntutan dunia usaha dan dunia industri, maupun perubahan dalam kehidupan masyarakat.

\section{Konsep Kampus Merdeka Belajar dalam Menghadapi Era Revolusi Industri 4.0}

Pendidikan selalu mengupayakan terciptanya mahasiswa yang selalu melakukan pembaharuan dari waktu ke waktu. Pendidikan tinggi tidak hanya mampu menjadi tempat perubahan dalam lingkup kecil maupun besar, sebab di kampus inilah mahasiswa memperoleh kematangan dalam menempuh pendidikan yang diharapkan mampu menjadi generasi dalam perubahan pola berpikir serta bertindak dengan baik sesuai yang diharapkan pemerintah. Selain itu, adanya kebijakan kampus merdeka ini perguruan tinggi diharapkan mampu melakukan berbagai inovasi dalam setiap proses pembelajarannya, baik pembelajaran yang berpusat pada mahasiswa sehingga mampu mendukung tercapainya kelulusan yang berkualitas yang siap menghadapi situasi zaman yang terus berevolusi.

Di dalam dunia pendidikan pemerintah berkontribusi langsung dalam menciptakan sebuah konsep kampus merdeka belajar. Salah satu konsepnya tersebut memberikan kebebasan selama tiga semester untuk melakukan tindakan yang membutuhkan sebuah pengalaman belajar maupun pengalaman sosial, dan tidak menyampingkan teknologi. Kebebasan tiga semester ini dilakukan di luar dari program studi, dengan tujuan agar dapat melahirkan 
lulusan terbaik dari perguruan tinggi yang akan terjun menjadi agen perubahan terbesar dalam beberapa kemajuan peradaban. Mahasiswa tidak hanya menjadi lulusan terbaik yang pandai dalam berteori akan tetapi mampu merealisasikan teori. Untuk dapat terlibat dalam kebijakan ini mahasiswa dimaksud harus berasal dari program studi yang terakreditasi, dan aktif yang sudah terdaftar pada PDDikti.

Secara umum konsep kampus merdeka antara lain: pertukaran pelajar, magang, asistensi mengajar di satuan pendidikan, penelitian, proyek kemanusiaan, kegiatan wirausaha, proyek independen, membangun desa/kuliah kerja nyata tematik (Direktorat Jenderal Pendidikan Tinggi Kementerian Pendidikan dan Kebudayaan, 2020).

Adapun pokok kebijakan pemerintah terkait dengan kampus merdeka belajar sebagai terobosan terbaru ialah:

1. Pembukaan program studi baru dengan arahan kebijakan saat ini:

a) PTN dan PTS diberi otonomi untuk membuka Prodi baru jika:

1) Perguruan Tinggi tersebut memiliki sudah akreditasi A dan B.

2) Sebuah Prodi boleh diajukan jika terjalin kontribusi dengan mitra perusahaan, organisasi nirlaba, institusi multilateral, atau universitas Top 100 ranking QS

3) Prodi baru tersebut tidak di bidang kesehatan dan pendidikan.

b) Kerja sama organisasi mencakup penyusunan kurikulum, praktik kerja, dan penempatan kerja. Kementerian akan bekerja sama dengan PT dan mitra Prodi untuk melakukan pengawasan.

c) Prodi baru tersebut otomatis mendapatkan akreditasi C Prodi baru yang tengah diajukan PT berakreditasi A dan B secara langsung mendapatkan akreditasi C dan BAN- PT. d) Tracer studi wajib dilakukan setiap tahunnya.

2. Program akreditasi perguruan tinggi dengan arahan kebijakan sebagai berikut:

a) Sebuah akreditasi ditetapkan oleh BAN-PT akan berlaku selama lima tahun dan dapat memperbaharui secara otomatis. Bagi perguruan tinggi yang terakreditasi $\mathrm{B}$ atau $\mathrm{C}$ dapat mengajukan kenaikan akreditasi secara sukarela.

b) Tindak Lanjut akreditasi akan dilakukan BAN-PT jika ada indikasi penurunan beberapa mutu.

c) Jika terdapat aduan masyarakat maka harus yang disertai dengan bukti nyata.

d) Jumlah pendaftar dan beberapa lulusan dari PT/Prodi tersebut menurun drastis lima tahun berturut-turut (ketentuan lebih lanjut tentang penurunan kualitas akan diatur melalui peraturan Dirjen terkait). Akreditasi A akan diberikan bagi Prodi yang sudah berhasil mendapatkan akreditasi internasional.

e) Pengajuan re-akreditasi PT dan sebuah Prodi dibatasi minimal dua tahun setelah mendapatkan akreditasi yang terakhir kali. Tracer study wajib dilakukan setiap tahunnya.

3. Sebuah perguruan tinggi negeri badan hukum, dengan persyaratan antara lain:

a) Untuk persyaratan untuk menjadi BH (Badan Hukum) dipermudah khusus untuk PTN BLU (Badan Layanan Umum) \& Satker (Satuan Kerja).

b) PTN BLU dan Satker bisa mengajukan kampus agar terjadi badan hukum dan tanpa adanya akreditasi minimum.

c) PTN dapat mengajukan permohonan menjadi BH kapanpun apabila kampus merasa sudah siap. 
4. Hak belajar tiga semester dari luar program studi, dengan arahan kebijakan sebagai berikut:
a) Perguruan tinggi harus wajib memberikan hak pada mahasiswa untuk secara sukarela.

b) Boleh mengambil sks dari luar perguruan tinggi sebanyak 2 semester (yang setara dengan 40 sks).

c) Boleh mengambil sks di Prodi berbeda di PT yang sama sebanyak 1 semester (yang setara $20 \mathrm{sks}$ ).

d) Sks wajib diambil di prodi asal sebanyak 5 semester dari total semester yang harus dijalankan (tidak berlaku untuk bagi prodi kesehatan).

Terkait dengan SKS ada perubahan terdefinisi atau paradigma, yaitu:

1) Sks merupakan jam dari kegiatan.

2) Semua jenis kegiatan harus dipandu oleh seorang dosen yang telah ditentukan oleh PT.

3) Mahasiswa dapat mengambil daftar kegiatan selama 3 semester tersebut dengan pilihan berbagai program dari pemerintah dan program yang disetujui rektor. Kementerian Pendidikan dan Kebudayaan, (2020).

Dari 4 poin kebijakan yang telah diterapkan pemerintah terkait konsep kampus merdeka belajar, ini sudah menunjukkan kepedulian yang besar terhadap perguruan tinggi di Indonesia, yakni agar perguruan tinggi tetap eksis dalam mencetak generasi Indonesia yang cerdas, beriman dan bertaqwa sehingga dapat menghadapi tantangan zaman yang terus berubah.

Menurut penulis konsep yang dicetuskan oleh Menteri pendidikan yakni Bapak Nadiem Makarim tersebut merupakan konsep yang sangat baik upaya untuk kemajuan pendidikan khususnya pada jenjang perguruan tinggi dalam menghadapi era revolusi industri 4.0 .

\section{Manfaat Program Kampus Merdeka Belajar dalam Menghadapi Era Revolusi Industri 4.0.}

Adapun manfaat yang dapat diambil dari adanya kebijakan program kampus merdeka belajar dalam menghadapi era revolusi industri 4.0 adalah sebagai berikut:

1. Konsep belajar tiga semester di luar Prodi, akan memiliki pengalaman belajar yang luas, dengan itu mereka dapat menemukan dimana sebenarnya passionnya.

2. Merupakan upaya untuk melatih mahasiswa dengan berbagai pengalaman belajar sehingga terbiasa dalam menghadapi tantangan di dunia nyata.

3. Pengalaman dan ilmu yang luas, bagaimana yang dikemukakan oleh Mendikbud, kurang lebih bahwa yang terpenting dalam periode pendidikan tinggi adalah menemukan kehausan untuk terus belajar, jatuh cinta dengan proses pembelajaran.

4. Kemudian kelebihan dari konsep kampus merdeka belajar pada poin hak belajar tiga semester di luar Prodi yakni para mahasiswa dapat menemukan di mana bidang ilmu yang disenanginya dan menemukan passionnya. Seperti dikemukakan oleh Mendikbud, kurang lebih bahwa masih terdapat mahasiswa yang merasa tidak sesuai dengan prodinya. (CNN Indonesia, 2020).

5. Sangat bermanfaat dalam menambah wawasan ilmu pengetahuan dan pengalaman belajar mahasiswa sehingga mereka lebih matang dalam menghadapi dunia pekerja, karena jika mahasiswa diberi kesempatan untuk belajar di luar prodinya, ia juga akan bersosialisasi dengan banyak orang, kemudian diharapkan dapat meningkatkan kerja sama antar sesama, sebagaimana yang dikemukakan oleh Mendikbud kurang lebih bahwa di dalam universitas saja masih terdapat sekat-sekat yang luar biasa, dan yang terbaik untuk mahasiswa yaitu kolaborasi antar 
fakultas baik di dalam universitas maupun di luar. (CNN Indonesia, 2020).

Dari apa yang telah dijelaskan di atas selaku penulis menganalisis bahwa atas teori tersebut, terkait dengan konsep kampus merdeka belajar di era revolusi industri 4.0 ini, sebagaimana yang dijelaskan sebelumnya bahwa pokok- pokok kebijakan merdeka belajar: Kampus merdeka terdiri dari 4 point antara lain: pembukaan program studi baru, sistem akreditasi perguruan tinggi, perguruan tinggi negeri badan hukum dan hak belajar tiga semester di luar prodi. (Kementerian Pendidikan dan Kebudayaan, 2020)

Untuk ini penulis menyimpulkan bahwa dengan adanya 4 poin kebijakan tersebut telah menunjukkan kepedulian yang besar terhadap perguruan tinggi di Indonesia, yakni agar perguruan tinggi tetap mampu dalam mencetak generasi Indonesia yang berintelektual tinggi, beriman dan bertaqwa sehingga dapat menghadapi tantangan zaman yang terus berubah.

Selain itu penulis berpendapat bahwa terkait konsep yang dicetuskan oleh Bapak Nadiem Makarim, merupakan sebuah konsep yang baik, dan merupakan bentuk upaya untuk kemajuan pendidikan khususnya pada jenjang perguruan tinggi dalam menghadapi era revolusi industri 4.0. Maka dari itu sebagaimana yang telah dijelaskan sebelumnya, penulis menarik kesimpulan bahwa pada era ini teknologi sudah menjadi bagian dari kehidupan manusia dalam membentengi segala kegiatan manusia pada zaman ini. Jadi, Sebagai generasi muda kita harus siap dan mampu dalam menghadapinya dengan sangat baik.

Menurut penulis terkait penjelasan di atas adanya kendala dalam menggabungkan setiap perguruan tinggi untuk bersama-sama berubah, baik dimulai secara perlahan dengan strategi dan metode yang inovatif atau dengan langsung terlebih dengan langsung menjalankan kebijakan kampus merdeka belajar tersebut dalam waktu yang singkat tentu masih membutuhkan waktu dan kesiapan. kemudian, dengan kebijakan ini penulis menganalisis bahwa konsep kampus merdeka masih kurang disosialisasikan, sehingga masih banyak yang belum memahami bagaimana konsep kampus merdeka belajar ini secara lebih detail lagi.

Penulis mengasumsikan solusi, bahwa untuk dapat menjalankan konsep kampus merdeka ini dibutuhkan kerja sama antar perguruan tinggi serta kebijakan ini perlu disosialisasikan secara lebih mendalam kepada pihak perguruan tinggi tentang pelaksanaannya, diantaranya kepada para dosen, dan juga kepada masyarakat. karenanya dengan kesiapan yang lebih baik lagi serta hendaklah konsisten agar tujuan yang ingin dicapai dan diharapkan terlaksana dengan baik.

\section{KESIMPULAN}

Kebijakan yang dicetuskan oleh menteri pendidikan yakni Bapak Nadiem Makarim adalah terkait dengan Konsep Kampus Merdeka Belajar yaitu terdiri atas empat pokok kebijakan yakni: pembukaan program studi baru, sistem akreditasi perguruan tinggi, perguruan tinggi negeri badan hukum, hak belajar tiga semester.

Adanya konsep kampus merdeka belajar yakni terkait dengan hak belajar tiga semester di luar prodi yang diharapkan mahasiswa mampu menjadi mahasiswa yang diharapkan bangsa dan negara yang lebih aktif, kreatif, inovatif, serta mereka diharapkan mampu bekerja sama dengan mahasiswa lainnya secara keseluruhan antar jurusan atau fakultas baik di dalam maupun di luar universitas, sehingga terjalinlah sebuah kerja sama yang baik, inilah salah satu bentuk konsep kampus merdeka, dimana proses pembelajaran dipusatkan langsung pada mahasiswa itu sendiri secara aktif sehingga akan terbiasa dihadapkan pada berbagai permasalahan, sehingga dapat biasa dalam menghadapi permasalahan dunia nyata.

Dengan adanya hak belajar di luar Prodi akan membuat mahasiswa dilatih bukan hanya di dalam kelas saja tetapi praktek ke 
lapangan bersosialisasi dengan masyarakat sehingga terwujudnya wawasan dan pengalaman belajar bagi mahasiswa. Munculnya konsep kampus merdeka belajar ini memberikan keluasan ilmu pengetahuan di berbagai bidang ilmu dan pengalaman belajar khususnya bagi mahasiswa sehingga mereka mampu menemukan dimana passionnya, siap dalam menghadapi dunia nyata sekarang ini, serta mampu menghadapi era revolusi industri 4.0 yang tidak akan kalah dengan mesin. Namun, manusia tetap menjadi pengendalinya.

\section{UCAPAN TERIMA KASIH}

Ucapan terima kasih yang sebesarbesarnya penulis ucapkan kepada pihakpihak yang terlibat di dalam penulisan artikel ini khususnya kepada:

1. Bapak Dr. Mohammad Rif'at selaku pembimbing penyusunan artikel ini.

2. Bapak Dr. techn. Zairin Zain, selaku ketua Seminar Nasional PIPT VI Tahun 2021.

\section{DAFTAR PUSTAKA}

Anwar, D. (2020, Maret 27). VIDEO: Kampus Merdeka ala Menteri Nadiem (45). Retrieved from CNN Indonesia:

https://www.cnnindonesia.com/tv/20 200327163200-411-487601/videokam-pus-merdeka-ala-menterinadiem-4-5

Kemendikbud. (2020). Buku Panduan Merdeka Belajar-Kampus Merdeka. Jakarta: Direktorat Jenderal Pendidikan Tinggi Kementerian Pendidikan dan Kebudayaan.

Fonna, N. (2019). Pengembangan Revolusi Industri 4.0 dalam Berbagai Bidang. Guepedia Publisher.

Joenaidy, A. M. (2019). Konsep dan Strategi Pembelajaran di Era Revolusi Industri 4.0. Yogyakarta: Laksana. 